\title{
Albert Camus'da Saçma ve Ölüm İlişkisi
}

\section{FATMA DIDEM ALTUNAY ERDUVAN*}

\section{Öz}

20. yüzyıl, varoluşçu düşüncenin ortaya çıkışının ve insana özgü tüm varoluşsal kavramların gözden geçirildiği bir çağ olmuştur. Savaşların ve değişimlerin yüzyılında ölüm ve yaşam arasındaki keskin ilişki, daha çok düşünsel yapının konusu olmuştur. Camus, saçma ile birey arasındaki bilinç merkezli ilişkinin ölüm ile daha farklı bir düzleme çekildiğini gösterir. Ölüm cezaları, intiharlar, toplu katliamlar ve sıradan ölüm olarak ölümün çok biçimliliği ona içkin olan anlamsal bağların çok anlamlılı̆̆ını da ortaya koyar. Zamanın dilimsel bağlarını tek düze eden ölüm, Camus için merkezi olan bir konu hâlini almaktadır. Saçma ve ölüm arasındaki bağ dünya ile insan arasındaki ilişkinin tarzlarını da meydana getirmektedir. Bu çalışmada, bu bağlamsal yapılar ve Camus'nun varoluşçu felsefede ana konuları üzerinde durulacaktır.

Anahtar sözcükler: Albert Camus, Varoluşçu Felsefe, Ölüm, Saçma

\section{THE RELATION OF ABSURD AND DEATH IN ALBERT CAMUS}

Abstract

The 20th century had been an era in which the emergence of the existentialist thought and all existential concepts peculiar to human beings were reviewed. In the century of wars and changes, the sharp relationship between death and life had been the subject of more intellectual structure. Camus shows that conscious-centered the relationship between absurd and individual is pulled to a different level with death. The polymorphism of death, such as death sentences, suicides, mass murders and ordinary death, also reveals the polysemy of the semantic ties inherent in it. Death, which unifies the segmental ties of the time, becomes a central issue for Camus. The link between absurd and death also creates the ways of relationship between the world and human. In this study, these contextual structures and main topics of Camus's existential philosophy will be discussed.

Keywords: Albert Camus, Existential Philosophy, Death, Absurd

\section{GíRiş}

900'lü yıllar, başka pek çok olayla birlikte iki büyük savaşın çağı olarak kendine özgü
tutumunu da inşa etmiştir. 20.Yüzyıl felsefesi varoluşçuluğun öne çıktığı, bireye özgü
olanın artık dünyanın merkezine geldiği bir döneme karşılık gelir. Yaşam, yaşam olarak benim olandır ama her türlü tehlikeye de açıktır. Bu yaşamın tüm yönleri artık felsefenin ana konusu olmaya hak kazanmıştır. Camus için de yaşamın en önemli bilinç uğrakları saçma ve ölümdür. Ölüm yaşamın karşıtı olarak bir çatışma unsurudur. Dünyaya içkin olan Ben'in

\footnotetext{
* Muğla S. K. Ün. Sosyal Bil. Ens. Felsefe Doktora Programı, didem_altunay@hotmail.com, orcid: 0000-0002-8447-5139
} 
dünyasının yok oluşunun varlığını hissettiği dirimli bir ölüm kavramı, Ben'in bilincinde dünyaya karşı bir yarık, boşluk ve mesafe oluşturur. Kimse ölüme yüz çeviremez, fakat asıl mühim olan insanın kendi yaşamına sırt çevirmesi ve bilinçli olarak eyleme geçerek intihara yönelmesidir. Camus için bu durum, bilincin o yarığı kendini açma potansiyelini ortaya koyar. Asıl felsefe, buna yönelmelidir.

Camus için ölümle olan ilişkimiz, saçmanın da bilincimizde ve yaşantımızda ortaya çıkışının merkezinde yer alır. Yapıtlarının çoğunda ölüm teması geçmektedir. Tersi ve Yüzü'nde yaşam ve ölümün karşıtlığının diyalektik ilişkisini, Caligua'da ölümsüzlük isteğinin tasvirini, Dü̆ğün'de Cezayir tabiatının yaşama bağladığı dinamizm ve ölümün sıradanlığını, Düşs̈ş'te ölümle yüzleşmenin korkunçluğunu, Sisifos Söyleni'nde intiharı, Veba'da toplu ölümün karşısındaki çaresizliği, Yabancı'da kendisinin-başkasının ölümü ve ölüm cezasının saçmayı ortaya çıkarışını, Başkaldıran Insan'da ölüme karşı uyumsuzun zaferini görürüz. Tüm yapıtlarında yaşama tutkusu ile dolu bir bünyede ölümü kabul edebilmenin güçlüğü ortaya konur. Camus kendi yaşantısında da ölümle sürekli kurduğu fiziksel ve bilişsel ilişkiden dolayı, "Ölüm karşında duyduğum tiksinti hayat kıskançlı̆̆ından geliyor" der. Ve ekler, "Birinci ile ilişkisi olan ikinci sınırlama, hayat kıskançlığından çıkar. Fizik tadın özü; tadın anlılığındadır, bir andaki geçiciliğindedir. Her şeyi ana bağlamak, her şeyi anında var olana bağlamak demektir." (Chruickshank, 1965, s. 60). An insanı şimdinin varlığına bağlar, şimdi yaşanan zaman dilimi ve varlığımın bütünsel bilinç hâlidir. $\mathrm{Bu}$ nedenle kahramanlarının anı yaşama kareleri çok etkileyicidir. Saçmanın kendisinden sıyrılmak anın dolu dolu yaşandığı tutkusal zaman dilimidir. Bunu en çok Camus'nun Mearsault ve Don Juan karakterlerinde betimlediği şimdinin duygusunu ve bedenin yaşam içindeki hâkim etkisini vurguladığı yerlerde görürüz.

\section{SAÇMA}

Dünya ile insan bilinci arasındaki, bağ sorunludur. Bu sorunlu oluştan dolayı hayat, anlamsızlaşmaya ve bilinç ile dünya arasında ciddi kopuşlar gerçekleşmeye başlar. Bu hâl uyumsuzla yani saçmayla yüzleşme anıdır. Akıl, kendi tutarlılık dünyasının dışına çıkar ve saçmanın izahını veremez olur. Bu boşluk, insanın varoluş sancısını betimler. Akıl, gündelik hayatın ve varoluşsal hayatın karşıtlığında çelişkiye düşer. Bilinç, bu anlamsal açıklı̆̆ı kapayamaz ve dünya ile insan arasındaki ilişki kopmaya başlar. Camus, gündeliğin bilincinin saçmayı ortaya çıkarmasının ardından, anın akıl temelli değil bedensel hazza yönelik yaşamsal akışını kabul etmeye davet eder. Bunu mükemmel bir doğanın içinde denizin kokusunu içinize çekerken, gün batımını seyre dalarak bulabilirsiniz. Doğa, saçmalığın paranteze alışını bize verir, fakat maalesef ki doğanın öz çocukları olmaktan çıkaran bir bilinç ve akıl sahibi varlık olarak insan bu paranteze alışı daha fazla tutamaz, çünkü Albert Camus'ya göre "Ağaçlar arasında bir ağaç, hayvanlar arasında bir kedi olsaydım, bu hayatın bir anlamı olacaktı ya da daha ziyade bu sorunun hiçbir anlamı kalmayacaktı, zira bu dünyanın bir parçası olacaktım..." (Camus A. , Sisifos Söyleni, 2013, s. 56).

Dünyanın bir parçası olmamak, dünyandan ayrı olarak varoluşsal özümün dünyayla hemhâl olma güdüsünden doğan çatışmayı ortaya koyar. Bir bunalım hâli, bir ayrık otu ruhunun 
betimleniş durumdur. Dünyanın içinde mevcut olarak onunla olan ilişkisel kopuşum saçmanın duyumsal deneyimini ortaya koyar. Camus için uyumsuz insanın yaşantısı, oyuncu ile dekor arasındaki ilişkisel kopuş gibi bir analoji ile anlamlandırılabilir. "Sisifos Söyleni"de "SaçmaUyumsuz Felsefesi" geliştirmediğini ancak "Saçma Duygusu"nu tasvir ettiğini söyleyerek bu saçma duygusunun da betimlemesini yapmıştır.

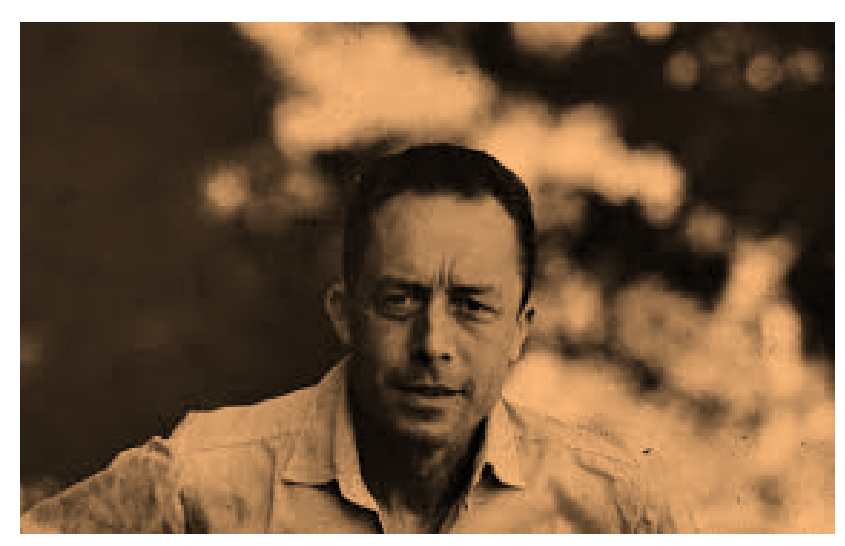

Saçma duygusu bir ayrımlaşmanın kaynaklık ettiği bir hâldir. "Absurde, bilinç ile dünya arasındaki ilişkiden ziyade ilişkisizlik ya da ilişkinin kopuşu, dünya ile bilinç arasındaki uyumsuzluktur." (Gündoğan, 2011, s. 100). Bu uyumsuzluk yani saçma duygusu dört bilinç hâlinde ortaya çıkar, çünkü Camus'ya göre, saçmalığı duyumsal olarak yaşantılayan ve bilincinde de olan dört ayrı insan yaşantısı vardır. İlk olarak, mekanik bir doğaya sahipmiş gibi modern dünyanın bize tek düze kıldı̆̆ı davranış örüntülerimiz. Yani bir otomat gibi her gün gündelik telaşlarla monotonlaşan yaşam biçimimizin ortaya koyduğu insan tipinin bu yaşama sırt çevirmeye niyet ettiğinde yaşadığı o duygu, işte bu ilk saçmanın duygusal olarak da deneyimini ortaya koyar. Yaşam aynı ritim üzerine sürekli gidip gelmek gibi sıradan ve bayağı olmaya başladığı an Yabancı olan o uyumsuz insan kendi kendine söylenmeye başlar: "Sabahleyin kalkmak, tramvaya binmek, büroda ya da fabrikada dört saat çalışma, yemek, tramvay, dört saat daha çalışma, yemek, uyku ve pazartesi, salı, çarşamba, perşembe, cuma, cumartesi hep aynı ritim üzere..." (Camus A. , Sisifos Söyleni, 2013, s. 24). Saçmayı deneyimleyen, yabancı olandır. O artık anlam ile dünya arasındaki bağın kopmuş bir çocuğu olarak gündelik benlik olarak yaşamını sürdürür. Camus'ya göre Yabancı yaşamın içinde hep gördüğümüz sıradan bir ayrıntıdan ibarettir. Bunda şaşıracak bir şey yoktur. Basit ve somut dünyanın saydam bir görüntüsünü bize verir. Değerler piramidini yıkan saflı̆̆1 iyikötü, doğru-yanlış üzerine verilen tüm yargıları tek düzleme indirger. Yabancı, iyi ile kötüyü, izin verilen ile yasak olanı öğreten papazın gelişinden önceki ilkel insanlar gibi suçsuzdur. Her şeyi yapmasına izin vardır. "Gülüşler ve kayıtsızlıklarla dolu, sürekli bir şimdiki zaman 'yaşayan prens Mişkin' gibi suçsuzdur." (Sartre, 1965, s. 92). O, sınırlı özgürlüğü ve geleceksiz başkaldırısıyla ölümlü bilincinden kuşkusu duymaz. Serüvenini, yaşamı süresince sürdürür. Alanı burasıdır, kendisininkinden başka her yargıdan uzak tuttuğu eylemi buradadır. (Camus A. , 2013, s. 71). Sonsuz şimdilikte kendine yönelir. Refleksiyonu kendi şimdisi üzerinedir.

İkinci olarak saçmanın deneyimi zamanın çizgisel ilerleyişine karşı parçalanmışlığını hissettiği andır. İnsan, geçmiş zamanı ve onun gelecek zamanla olan ilişkisini sınamaya başladığında yaşamın akışının ilerleyişini hisseder. Bu süreç ölüme doğru yol alan ve ölümle sonlanacak olan bir süreçtir. Ölüm, yaşamın bir gerçekliği olarak bilincinde olduğum bir varoluş koşuludur. Yaşamın, ölümün karşısındaki durumu neyse uyumsuz insanın, uzlaşmış insan karşısındaki durumu odur. İşte ondadır ki bu karşıtlık uyumsuz olanı yabancı kılar. “Uyumsuz da her şey gibi ölümle biter böylece. Ama bu dünyanın dışında da uyumsuz olamaz" (Camus A. , 
Sisifos Söyleni, 2013, s. 39). Dünyaya içkin olan ölüm ve uyumsuz dünya merkezinde birbiriyle bağ bulur, fakat hem uyumsuz hem de ölüm dünyanın dışına çıkma eğilimi gösteren varoluşlarını dünya içinde oluşturmaya çalışır. İnsan dünyanın bir parçası olmayı başaramayan ama onun içinde olan varlık, ölüm dünyanın içinde varlığını göstermeyen ama dünyanın parçası olan bir koşuldur. Dünyanın içinde “tek çıkış yolu ölüm olan bir yazgıdır. Ölümün bu tek kaçınılmazlığı dışında, sevinç ya da mutluluk, her şey özgürlüktür. Bu özgürlük içindeki dünya, tek efendisi insan olan bir dünyadır, sürer gider"' (Camus A. , Sisifos Söyleni, 2013, s. 120).

\section{ÖLÜM}

Özgürlük ile ölüm arasındaki ilişki hep ölüm lehine kazanılmış bir savaş olmuştur. Ölüm, insansal sınırların bünyesi içindedir. Ölüm ve saçma, akılsal sınırlar içinde direnişi ve çatışmayı ortaya çıkarır. Ölüm olayı ve saltıklar yoksunluğu masumluk ve özgürlük ile birleşerek yaşama yoksunluğunu saçma insan'ın onaylayabileceği bağdaşımlı bir duruma sokar. Mühim olan, bu insanın olabildiği kadar mertçe yaşaması değil, olabildiği kadar dolu olarak yaşamasıdır (Chruickshank, 1965, s. 104). İntihar ya da cinayet yönünde bir eylem seçmiyorsa insan, tam o noktada gerçek başkaldırı olarak ölüme karşı yaşama başkaldırısını ortaya koyar. Bu nedenle Camus yaşama bağlı olmayı en değerli eylem sayar "Dünyada en saygı duyduğum değer olan yaşamın, hiçbir şeyini yadsımayan bir yaşama isteğidir bu" demektedir (Camus, 2015, s. 127). İnsanın içindeki en büyük çatışmaya karşı başkaldırması şarttır. Bu başkaldırıda en büyük güç kaynağ1 ise yaşama sevgisinin ölümün soğukluğu karşısında iç ısıtan duygulanımıdır.

Saçmanın en son ve geri döndürülemez olarak yaşandığı an ölüm anıdır. Ölüm, kabul edişin ya da ona karşı çıkışın bilinci tüm yıkıcılığıyla saçmanın en çarpıcı tecrübe hâlidir. Ölümün kendisi öylece fırlatılmış ve bırakılmış olan varlığın öylece oradan silinmesi ve bağlarının koparılmasıdır. Ölüm ile yaşam arasındaki insan Camus için ölüm ve saçmanın gerçekliğine rağmen yine de yaşamdan yana tutum sergilemelidir. Camus'nun uyumsuz insanı saçmanın gerçekliğini kabul eder. Fakat ona karşı özgürlük mücadelesi verir yani başkaldırası yaşam merkezlidir. Yaşamda umut olmaksızın tutunabilmek mümkün değildir. Bu nedenle Camus'da isyanın yıkıcılığından ziyade en güzel meyve olarak uyumsuzun pesimist yapısından sıyrılma görülür. Yaşam, tüm yaşanılamazlıklara rağmen yaşanılasıdır. İnsan çaresizce farkına vardıklarının ardından yıkılan anlam dünyasını, yine kendi farkındalığıyla ve kabullü boyun eğişe çevirme değil de başkaldırmaya dönüştüren ruhuyla yeniden inşa edecektir. "Ölüm yaşama aşkına, intihar düşüncesi ve umutsuzluk umuda, uyumsuz ve anlamsız olan en sonunda anlamlı ve değerli olana dönüşüyorsa, bütün bunlar, Camus'nun doğayı, insanı ve hayatı sevmekten yorulmadığı içindir. " (Gündoğan, 2011, s. 22).

Sürekli değişen benliğimiz aynı zamanda ölüm yönünde bir varlık oluşumuzu, varlığımızın kararsız ve geçici niteliğini ortaya koyar. Bu geçicilik hâli hayata karşı tavır almamızı sağlar. Bu durumda hayattan yana tavır alırsak Nietzsche gibi, Amor fati, kaderini sev diyebiliriz, fakat ölümden yana tavır alırsak dini vaatlerin işaret ettiği gibi öte hayattan yana tavır alır ve bu dünyanın geçiciliğini esenlikle kabul ederiz. Camus bu dünyadan vazgeçen şimdiden yana olmayıp hep geleceğe entegre olmuş hayatı yadsır. Ölmek zorunda olduğunu bilen insanın en 
doğal arzusu Camus'da yaşama deneyimlerini çoğaltmak olabilir. Her anın değeri, anın sürüp gitmesini sağlayacak nitelikle ilgilidir. Öyleyse ölüm hayatı değiştirir (Gündoğan, 2011, s. 119). Anlar çokluğu olarak birey şimdilerin duygu geçişliliğini de aklın sert yasaları olmadan yaşayabilmelidir. Sevgisini, öfkesini ya da sevincini şimdi ve burada nasılsa öyle dolu dolu yaşayabilmelidir. Anlar çokluğu yaşama sevincinin şiddetini ve derecesini de gösterir.

Uyumsuzluğun görüldüğü bir diğer nokta ise insanların çoğunun farklı boyutlarda ve etkilerde hissettiği yabancılaşma duygusu ve bu dünyaya öylece bırakılmış olma hâlidir. Burada en çok tek başınalık duygusu hâkimdir. Bu duygu, insanın öz varlığının rastgele ve gelişigüzel olarak bu dünyaya sunulmuş olmasıdır. Birey, başkalarına karşı ayrık otu olma durumunu içkin olarak yaşantılar. Bu deneyim hem başka insanlarla hem de bu dünyayla bağını koparır. Yabancılık, bireyler arası ilişkilerde de anlam üzerine boşlukların çoğalmasıdır. İnsanın öylece bırakılmış olmasının yanı sıra ölümlerin sıradanlaşmasıdır. Yabancı olma, başkalarına karşı onlardan başkalaşmış olma hâlidir. Akşam vakti kahvesini içip sokağa bakan biri, yolda kaza sonucu ölen birine tanık olur. Kahvesini yudumlamaya devam eder ve perdeyi çekerek salondaki koltuğa uzanır. Yabancı olan dünyaya karşı değil, başkalarına hatta başkalarının dünyasına karşı da mesafe alır. Dünyaya öylece gelmiş ve dünyadan öylece gidecek olmanın saçma duygusu, insanda başkalarına dair kaygıdan ziyade şimdide ölümle yüzleşirse kendi yaşanmamışlıklarına dair kaygiya odaklanır.

Camus başkaldıran insanın yaşamı değil, yaşamın nedenlerini istediğini belirtir. Ölümün yaşattığı tüm sonuçları yadsır. Hiçbir şey sürekli değilse, hiçbir şey doğrulanmamışsa, ölen anlamdan yoksundur, ölüme karşı savaşmak, yaşamın anlamını istemek, kural ve birlik için çarpışmak anlamına gelir (Camus, 1985, s. 96). Ölüme karşı açılmış olan savaş en büyük başkaldırı hamlesidir. Bu savaş, yaşama bağlılığın ve varoluşsal serüvenin devamlılığını istemenin ölüme karşı savaşıdır. Öyle ki intihar, ölüm cezası ve cinayetler böylesi varoluşsal mücadeleyi kesintiye uğratmak bakımından kabul edilebilir değildir. Camus, intiharın gerçekten önemli bir felsefe sorunu olduğunu düşünür. Hatta yaşamın yaşanmaya değip değmediği konusunda bir yargıya varmak, felsefenin temel sorusuna yanit vermektir (Camus A. , 2013, s. 15). Camus, intiharın neden bir tercih olduğunu sorgulamayı kendine uğraş edinir. Neden insan kendi ölümünü ister? Hatta buna onu iten arzu nereden kaynaklanır? Bu arzu etme hâli eylemsel gerçekliğe nasıl ulaşır? Dahası neden bir insan başkasının ölümünü ister? Bu ölümü gerçekleştirmek için savaşlar, cinayetler, idamlar nasıl gerçekleşir? Peki çocuk ölümleri... Tüm bunlar üzerinde düşünüldüğünde Tanrı, neden masumların ölümüne izin vermektedir? Vebalar, savaşlar en masum ve savunmasızları neden ilk önce öldürür? Tüm bunlar ölüme karşı ve onun nedenlerine karşı başkaldırıyla nihayete erer. Her şeyi yıktığını, her şeyi kendisiyle birlikte götürdüğünü sanır insan ama bu ölümden bile, belki de yaşamaya değecek bir değer doğar. Salt yadsıma intiharla tükenmez (Camus, 1985, s. 5). İntihar etmekle kişi saçma olan tüm anlam yokluğunu değil, kendi varoluşunu sonlandırır. Uyumsuz insan, uyumsuzla sonuna kadar mücadele etmelidir. Uyumsuzluğa, saçmaya, ölüme karşı insan başkaldırarak yaşamayı seçmelidir. Bu nedenle intihar, ölüme karşı bir başkaldırma değil, onun kabulü olur. Ölüme mahkûm olduğunu bilmek, bu bilinçten dolayı başkaldırmak, intihar düşüncesiyle bağdaşmaz. İntihar edenle, ölüme mahkûm 
olduğunu bilen insanların durumunu Camus, birbirine karşıt durumlar olarak gösterir. İntihar eden intihar etmekle uyumsuzu ortadan kaldıracağını düşünür, oysa yanılır. Çünkü intihar bir yanılgıyı ortaya çıkarır (Gündoğan, 2011, s. 144). Camus'ye göre ölümü tercih etmek yaşamla mücadele etmekten daha basittir. İnsan, olması gerektiği yerde olmak ister. Buna ulaşamayabilir. Ama kimi kez yaşamak için, intihar etmekten daha çok cesaret gerekir (Camus, 1991, s. 68). Yaşam kişinin kendini aşma problemini de ortaya koyar. “Kendini öldürmek, bir anlamda, melodramlarda olduğu gibi içindekini söylemektir. Yaşamın bizi aştığını ya da yaşamı anlamadığımızı söylemektir" (Camus A. , 2013, s. 16).

Camus'ye göre ölüm aynı zamanda adalet problemidir. Ölüm, haksız bir kesinlik olarak orada öylece durmaktadır. Öldürülme veya öldürmeden de öte salt ölümün duru gerçekliği vardır. Dünyada savaşlar kadar vebalar da meydana gelmiştir. Vebalar da savaşlar da insanı hazırlıksız yakalar (Camus, 2009, s. 40). Ölüm, hep hazırlıksız ve haksız bir geliştir. Bireysel olarak da "başkaldırmış kişinin evreninde, ölüm, adaletsizliği aşka getirir. O, son haksızlıktır" (Camus A. , 2013, s. 92). Ölüm, "sonu olmayan yıkım”dır (Camus, 2009, s. 116). Bu yıkım öngörülmediği gibi durdurması da mümkün olmayan bir varoluş yüzleşmesidir.

Ölüm karşısında tavrımız insani boyutta da değerler dizilimimizi gösterir. Özellikle veba gibi salgın hastalık hâllerinde insanların birbirlerine karşı müdahalesi, dünyaya takındıkları tavır ve adalet duygularının sarsılması aslında hakiki olan gerçeklik düzlemini de ortaya çıkarır. Günümüzde hâlihazırda Covid -19 virüsüne karşı insanların ve devletlerin tutumu ölüm tehdidi altında yaşamak, dünya içinde varlık olarak insanın mücadelesini de ortaya koyar. Bunun da ötesinde ölümün devletlerce seçilimin yani kimin feda edilebileceğini ya da milletlerin birbirine karşı tavrını adaletin ve ahlaki yargıların nasıl biçim değiştirdiğini gözler önüne serer. Camus'da bu nedenle varoluşun ölüm karşısındaki hatta ölüm biçimleri ve ölümün öznesi karşısındaki tavrını daha çok önemser. Kim ölüyor? Ben mi yoksa başkası mı? Nasıl bir ölüm gerçekleşiyor? İntihar, cinayet ya da hastalık sonucu bir ölüm mü? Tüm bu sorulara cevap yaşam tutkusu karşısında ölümün varlığının çarpıcılığına bizi götürür. O hâlde asıl saçma duygusu yaşam karşısında ölümün varoluşunun, bireyin bilincinde gerçekliğini var etmesi ve inkâr edilemez kesinlikteki duruşudur. Ölüme karşı açılan savaş Sisifos'un verdiği mücadelede görülür. Sisifos yazgısına başkaldırır ve ölümü zincire vurur, fakat onun zincire vuruluşu monotonlukta aynı bitimsiz mücadeleyi vermesidir. Ölüm karşısında esir kalmak, onun varlığını görmezden gelerek gündelik hayatın yaptırımlarına boyun eğmektir. Hepimiz otomat varlıklara dönüşerek, bilincinde olduğumuzu yeniden canlandırmaktan kaçınırız. Ölüm aslında gündeliğin kaçışı olarak örtük bir kavramdir.

Camus, örtük olan kavramin duygu betimlemesini ortaya koyarak açı̆̆a çıkarır. Amacının saçma felsefesi değil, onun duygusunu tasvir etmek olduğunu belirtirken aslında Yabancı romanındaki, çoğuna göre tanımlayamadı̆̆ duyguyu "Saçma Duygusu"nu okuyucuya

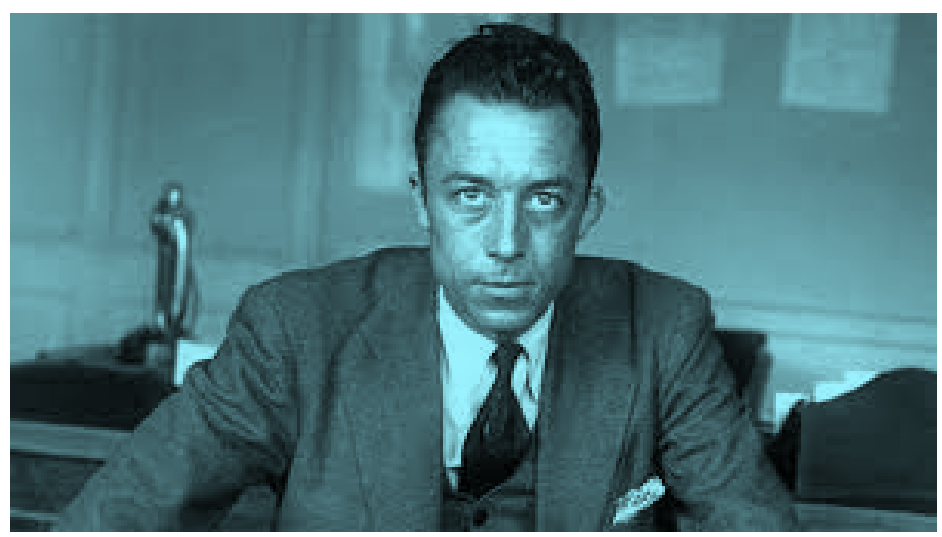


çoktan aşılamıştır, çünkü anlam vermekte güçlük çektiğimiz bu adam yani yabancı karakterindeki Mearsault öfke, acıma ya da korku duygusu uyandırarak insanlarda düşünceden daha çok duygulanım yaratır. Dünyanın kendisi yani aslında yaşamın kendisi duygulanımın hâkim olduğu bir alandır. Oysa akıl kıskacında insan kavramların hâkimiyetinde yaşamın bedensel yanlarını arka plana atmıştır. Doğanın kendisinin neliği doğanın kendisinin yaşamsal tecrübesinin duygularını ortaya koymaz. Saçma, dünya ile kopuşun bilincindeyken yaşama sırt çevirerek yaşam zorunluluğunun da bir sonucudur. Ölüm ve saçma arasındaki ilişki, insanın örtük akıl ve beden mücadelesinin sonucudur aynı zamanda. Bu nedenle Camus doğal olan ölüm ile bilinçli olan ölüm arasındaki ayrımda saçmayla yüzleşen bireyin ölüme karşı bilincine rağmen ona karşı takındığı gururlu ama mücadeleci olmayan intiharı merkez kavram olarak alır. Sisifos'un trajik durumu da gerçek olanın bilincinde olmasıdır. Sisifos "Düşkün durumunun bütün enginliğini bilir." Sisifos için bu dünya değersiz ve anlamsızdır. Fakat onun her taşı taşıdığı ve yeniden o taşın yere yuvarlanarak aşağı indiği anda "Taşın ufacık parçalarının her biri, bu karanlık dağın her madensel parıltısı, tek başına, bir dünya oluşturur. Tepelere doğru tek başına didinmek bile bir insan yüreğini doldurmaya yeter." (Camus A. , 2013, s. 126). Sisifos, umudunu yitirmeden yaşama tutunur. "Sisifos'un bütün sessiz sevinci buradadır. Yazgısı kendisinindir." (Camus A. , 2013, s. 134).

\section{SONUÇ}

Camus felsefesinin ana kavramları olan saçma ve ölüm insanın iki boyutunu göstermektedir. İnsanın, dünya içinde olan bir varlık olarak dünya ile olan ilişkisi kopmuştur. Bu kopuş onu saçma içinde kılar. Düşkün hâlde yüz yüze geldiği ölüm aslında yaşadığı dünya ile olan bağsızlığını da ortaya koyar. Saçma, ölümün gerçekliği ile daha çok varoluşsal bir anlam kazanır. Gündelik rutinler ile kendini ve dünyayla olan ilişkisini kesintiye uğratan otomat insan, trajik olanın tecrübesini yaşar. Camus ölümün iki biçimini felsefesinde yer vermiştir. Kendi ölümüm ve başkasının ölümü olarak. Başkasının ölümünün anlamını Yabanci'da Mearsault'nun annesinin ölümüne ilişkin sözlerini de buluruz. Annesi ölmüştür belki dün, belki de bugün ve Mearsault için bu tarihin önemi yoktur. Ölüm başkası için doğal bir biyolojik gerçekliktir. Kendi ölümüm ise dünya ile olan kopuşumun farkındalığını bana yaşatan ve beni yeniden dünyanın içine koyan bir gerçekliktir. Ondan kaçamam ve ona doğru gidişim yaşam sevincimin yitirilişidir. Kendi ölümüm varoluşsal bir gerçeklik olarak dünya ile tüm bağlarımı yeniden sorgulamamı ve yeniden kopmuş olan ilişkimi gözden geçirmemi gerektirir.

Camus ölümün bu iki biçimi dışında kendi ölümümü ilgilendiren birinin ve bir şeyin benim ölümüme sebep olması ve kendi ölümüme kendimin sebep olması gibi iki olguyu da ortaya koymuştur. Bir cinayet ya da bir kaza, hastalık, idam bunlar benim ölümümün dişsal sebepleri olarak benim irademin dışındadır. İntihar ise asıl Camus için felsefenin ilgilenmesi gereken konudur. Kendi ölümümü kendimin istemesi ciddi bir felsefi problemdir. Çünkü Sisifos gibi saçmanın içinde yaşıyor olsam da sessiz bir sevinçle yaşama yine umutla bağlanan bir özne tasavvur etmiştir. Bunun aksi ise yaşama tamamen sırtını dönen ve saçmanın tecrübesini dünya ile ilişki kurma döngüsüne girmeden kesen insanın kararıdır. Yani intihar gerçekten bir seçim mi 
yoksa bir cinayet mi? Camus bunu bir sürükleniş olarak modern insanın rutin, mekanik hayatındaki anlamsızlı̆̆ı ve doğa ile olan bağının kopuşu gibi görmektedir.

Camus doğa ile insan arasındaki mekanik parçalanmayı ve bu parçalanmış bireyin uyumsuzluğunu en açı biçimde ölüm kavramı deneyimlediğimizi ifade etmiştir. Doğa ile uyum hâlindeki birey mutlu ölüm gerçekliğiyle karşılaşır. Mutlu Ölüm'de de bunu ifade etmiştir. Ölüm anları Camus'nun eserlerinde doğa ile bir bağın yeniden kurulduğu bir uyum çağrısıdır. Başkaldırı da umut, saçmada da dünyaya uyum isteği vardır. Mutlu ölüm saçmaya karşı da bir başkaldırının sonucudur.

$\mathrm{Bu}$ incelememizde genel olarak Camus eserlerinde saçma ile ölüm kavramlarını ele alarak saçmanın ölüm gerçekliğinin de bir deneyimi olduğunu ve aralarındaki ilişkinin insan ile dünya arasındaki ilişkiye karşılık geldiğini ifade ettik. Bu ilişkinin kopuşu yani dünya ile insan arasındaki mesafenin artması nedeniyle uyumsuzluğun oluştuğunu, insanın bu uyumsuzluğu ölüm ile karşı karşıya geldiğinde bilincine eriştiğini belirtmiş olduk. Başka bir ifadeyle Camus'da doğa ve insan arasındaki organik bağın yeniden kurulması isteği, saçmanın yok oluşu yani dünya ile uyum isteğidir. Bu isteğin gerçekleşmesi ölümün de bir mutlu ölüme ulaşmasıdır. Mekanik insan varoluşsal kaygıları ancak saçma ile deneyimlediğinde anlayabilir. Bu mekanizmayı kıracak olan saçma ancak dünya ile uyum sağlandığında bireyin dünyasını kendisinin kılar. Ölüm ve saçma ilişkisi bu anlamda yeniden kişinin kendisine dönüşü ve yeniden doğa, dünya ile uyumu sağlamasıdır.

\section{KAYNAKÇA}

Camus. (1971). Sıkı Yönetim. (B. Onaran, Çev.) İstanbul: Yankı Yayınları.

Camus. (1985). Başkaldıran İnsan. (T. Yücel, Çev.) Ankara: Kuzey Yayınları.

Camus. (1991). Mutlu Ölüm. (R. Dara, Çev.) İstanbul: Can Yayınları.

Camus. (2009). Veba. (N. T. Öztokat, Çev.) İstanbul: Can Yayınları.

Camus. (2012). Terzi ve Yüzü. (T. Yücel, Çev.) İstanbul: Can Yayınları.

Camus. (2015). Dü̈̆̈̈n Bir Alman Dosta Mektuplar. (T. Yücel, Çev.) İstanbul: Can yayınları.

Camus, A. (2011). Yabancı. (V. Günyol, Çev.) İstanbul: Can Yayınları.

Camus, A. (2013). Sisifos Söyleni. (T. Yücel, Çev.) İstanbul: Can Yayınları.

Chruickshank, J. (1965). Albert Camus ve Başkaldırı Edebiyatı. (R. Güren, Çev.) İstanbul: De Yayınevi.

Erçel, G. (2013). Albert Camus Özgürlük ve Devrim. Kafe Kültür Yayıncılık.

Gündoğan, A. O. (2011). Albert Camus Hayatı, Yapıtları, Felsefesi. Bursa: MKM Yayınevi.

Özçınar, Ş. (2002). Albert Camus'nun Başkaldırı Felsefesindeki Varoluşçuluk ve Nihilizm. Felsefe Logos, 79-98.

Sartre. (1965). Yabancı'nın Açıklaması. (B. Onaran, Çev.) İstanbul: De Yayınevi. 
TÜRK BILİMKURGU

EDEBIYATI

VE ARKETIPLER

DR. VELİ UĞUR

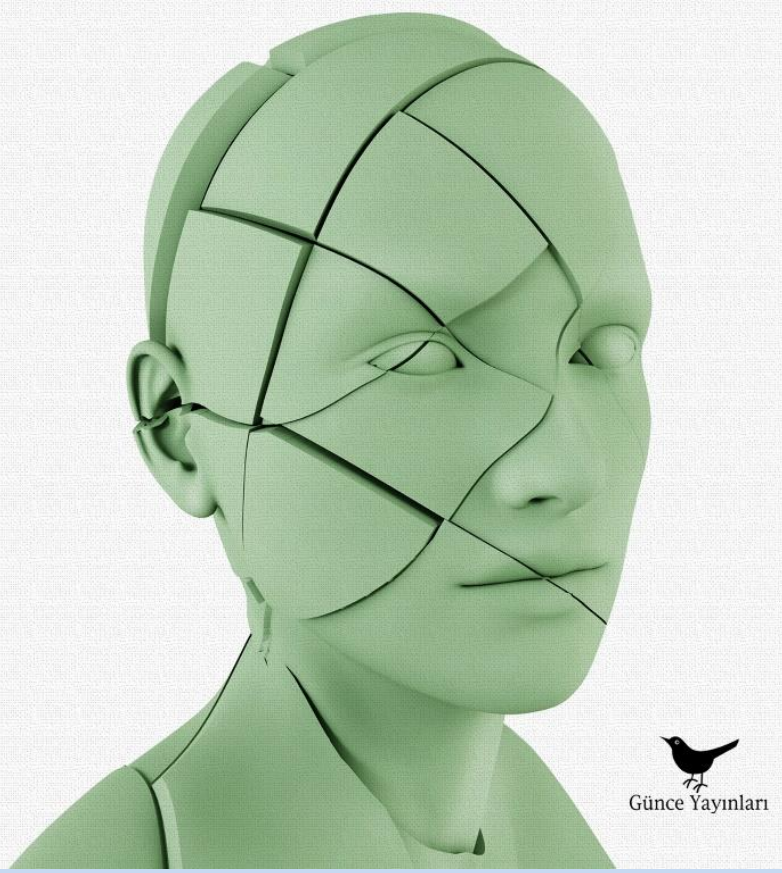

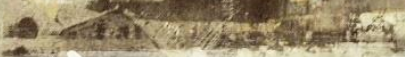

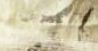

Jktdl| Џill|

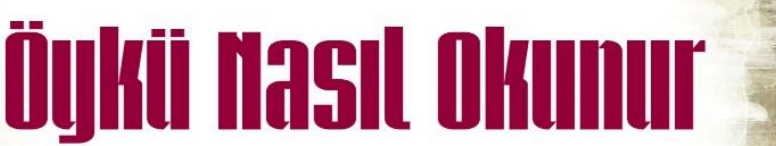

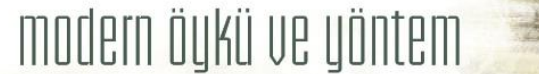

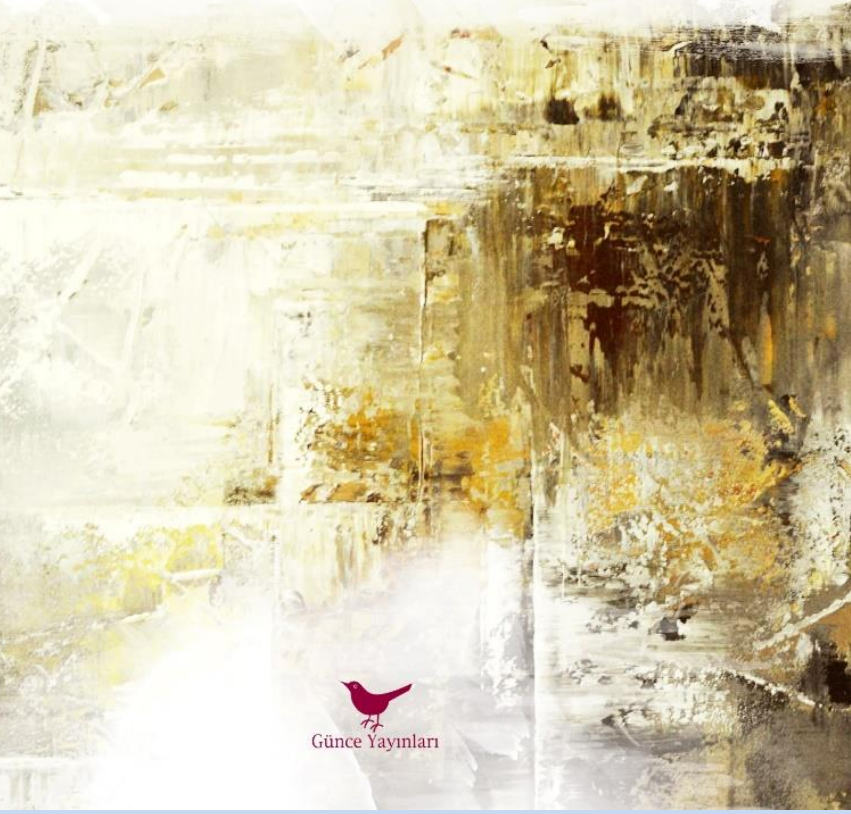

\section{Yazma Sanatı}

Edebivatutn Ebemklusăgu|

Halit Zijya Hilkâyecilliğinde Renklerin Dili

\section{MAKSUT Yit̆̈itBAŞ}

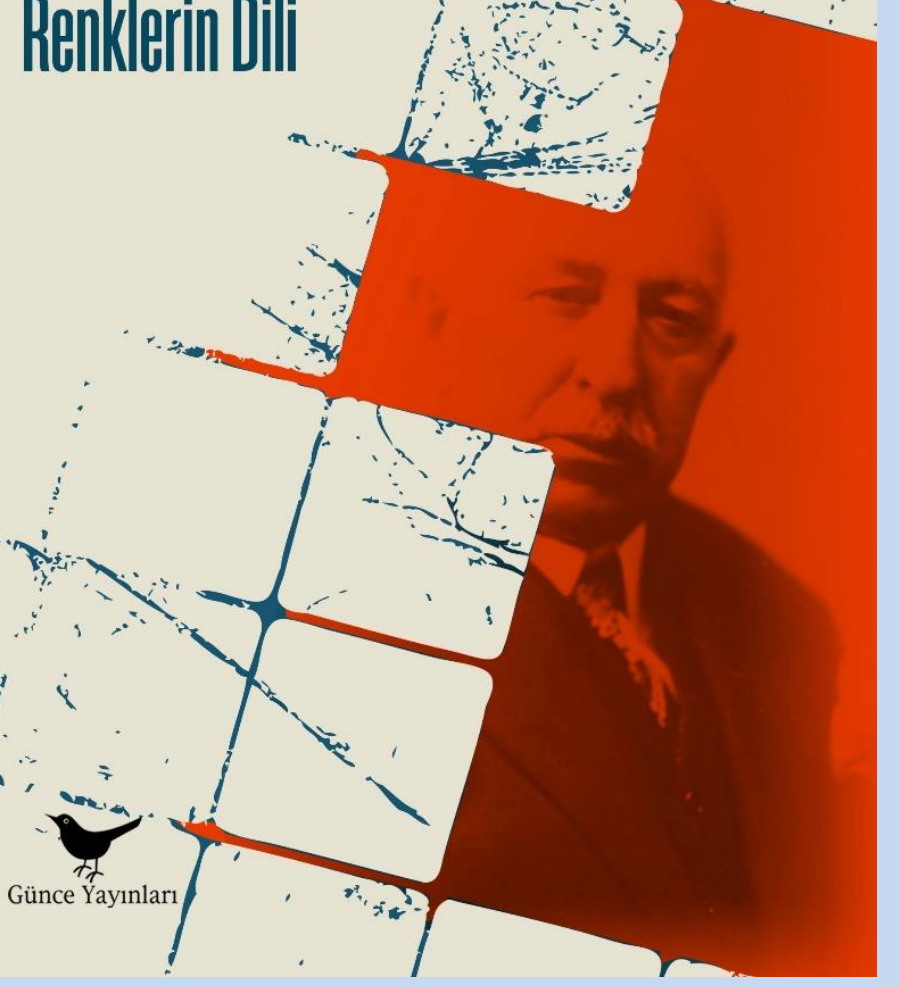

Türkçe Doğru ve Etkili Yazma Teknikleri

Prof. Dr. Önder Göçgün 